Sagar Krupa

University of Minnesota, St. Paul

Margaret Tuttle McGrath

Cornell University, Riverhead, NY

Christian P. Andersen

U.S. Environmental Protection

Agency, Corvallis, OR
Fitzgerald L. Booker

Kent O. Burkey

USDA-ARS Air Quality Research

Unit, North Carolina State

University, Raleigh

Arthur H. Chappelka

Auburn University, Auburn, AL
Boris I. Chevone

Virginia Polytechnic Institute \& State

University, Blacksburg

Eva J. Pell

Pennsylvania State University, University Park

Barbara A. Zilinskas

Rutgers University, New Brunswick, NJ

\title{
Ambient Ozone and Plant Health
}

T o those disciplinarians, we add plant scientists who consider that surface level ozone $\left(\mathrm{O}_{3}\right)$ poses a critical threat and a challenging problem to present and future world food, fiber, and timber production and conservation of natural plant communities, including their species diversity. In 1840, the German scientist C. F. Schönbein (43) suggested the existence of an atmospheric constituent with an electrical odor freed in noticeable amounts during thunderstorms (lightning). He proposed the name ozone $\left(\mathrm{O}_{3}\right)$ for this substance. It was chemically proven to exist at the ground level by Houzeau in 1858 (19). Soon thereafter, measurements were commenced at more than 300 stations to determine relative atmospheric $\mathrm{O}_{3}$ concentrations. One hundred years had elapsed since those first measurements before Richards and coworkers (39) showed in 1958 that $\mathrm{O}_{3}$ was a constituent of smog causing foliar injury to grape in California. During the following year, Heggestad and Middleton (18) reported that $\mathrm{O}_{3}$ was responsible for flecking on tobacco leaves in the eastern United States. Similarly, Daines et al. (7) identified $\mathrm{O}_{3}$ as the predominant air pollutant affecting agriculture in New Jersey. Since those early investigations, it has become evident that $\mathrm{O}_{3}$ is by far the most important air pollutant toxic to plants worldwide. Ozone causes foliar injury and reduces growth and yield in many agronomic and horticultural crops, deciduous trees, and conifers (26). As population, urban centers, and industries have grown, an increasing number of reports have appeared during the past 25

Dr. McGrath's address is: Department of Plant Pathology, Long Island Horticultural Research and Extension Center, Cornell University, 3059 Sound Avenue, Riverhead, NY 11901-1098; E-mail: mtm3@cornell.edu

Publication no. D-2000-1106-01F

(c) 2000 The American Phytopathological Society years regarding $\mathrm{O}_{3}$-induced foliar injury on sensitive plants in many countries. These include Australia, Austria, Belgium, Canada, France, Germany, Greece, India, Israel, Italy, Japan, Mexico, the Netherlands, Pakistan, Peoples Republic of China, Poland, Russia, Spain, Sweden, Switzerland, Taiwan, United Kingdom, and Ukraine.

\section{Occurrence of Ground Level Ozone}

Atmospheric ozone $\left(\mathrm{O}_{3}\right)$ is part and parcel of global climate change. Although ozone at the ground level is a "greenhouse gas," it plays a minor role in regulating our air temperature, contributing only about $7 \%$ to the total warming effect (23). There is also a naturally occurring beneficial $\mathrm{O}_{3}$ layer in the upper atmosphere (between 15 and $50 \mathrm{~km}$ above the surface) that strongly absorbs harmful ultraviolet radiation (about 210 to $290 \mathrm{~nm}$ : radiation $<280 \mathrm{~nm}$ is UV-C and 280 to $315 \mathrm{~nm}$ is UV-B). In contrast, there are both natural and humanmade sources of $\mathrm{O}_{3}$ at ground level. $\mathrm{Be}$ cause of these natural sources, there is a background average $\mathrm{O}_{3}$ concentration of roughly 20 to $30 \mathrm{nl} /$ liter (ppb) everywhere (10). It is highly questionable whether there is any place on earth that has not been influenced by modern-day human activity, and therefore background values will vary with location. Natural sources consist of lightning during thunderstorms and downward intrusions of $\mathrm{O}_{3}$ from the upper atmosphere.
The most important mechanism for the formation of $\mathrm{O}_{3}$ at the earth surface, however, is driven by sunlight (photochemical cycle). The two key precursors (volatile hydrocarbons and the oxides of nitrogen) required in the reaction cycle are also produced by natural biological processes, although their contribution is much less important than that from fossil fuel combustion (10). In this context, because of the seasonal changes in the intensity of the sun, high concentrations of $\mathrm{O}_{3}$ occur during the plant-growing season. Ozone is the major constituent of photochemical smog (a combination of smoke and fog), the oxidant complex that includes peroxy acyl compounds (e.g., peroxy acetyl nitrate [PAN]) and the oxides of nitrogen (10).

Figure 1 provides an idealized daily pattern of $\mathrm{O}_{3}$ and its precursors in the photochemical reaction. Emissions of nitric oxide (NO) and hydrocarbons (HCs) are high in the early morning as a result of heavy urban traffic during the rush hour. These vehicular emissions destroy some of the $\mathrm{O}_{3}$ present at that time, leading to the conversion of $\mathrm{NO}$ to $\mathrm{NO}_{2}$ (nitrogen diox-

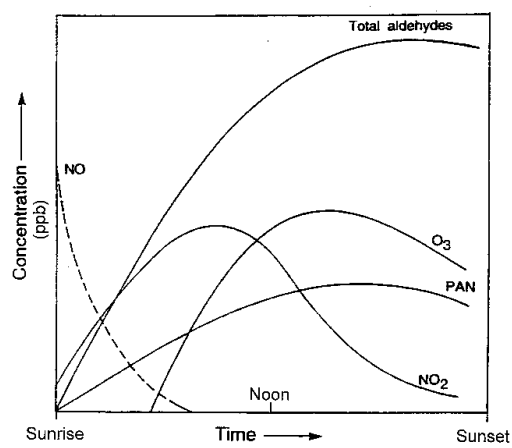

Fig. 1. Idealized diurnal profiles of the reactants (e.g., $\mathrm{NO}_{2}$, nitrogen dioxide, and total aldehydes or hydrocarbons) and products (e.g., $\mathrm{O}_{3}$ and PAN, peroxy acetyl nitrate) in photochemical air pollution (Krupa [22]). 
ide, one of the precursors for $\mathrm{O}_{3}$ ). The $\mathrm{NO}_{2}$ concentrations reach peak values when the atmosphere has developed sufficient capability to oxidize NO without totally consuming $\mathrm{O}_{3}$. This process involves the sec-

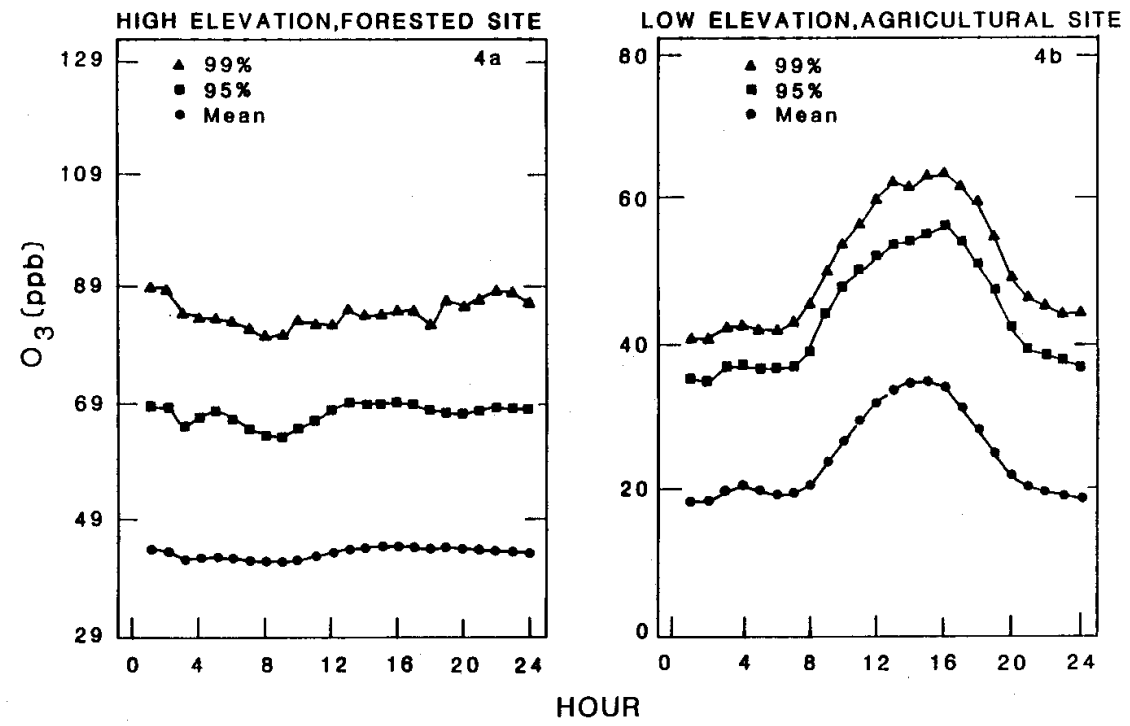

Fig. 2. Daily patterns of hourly mean, 95 th and 99 th percentile $\mathrm{O}_{3}$ concentrations $(10 \mathrm{~m}$ above the surface). Comparison of results from a higher elevation $(2,103 \mathrm{~m}$ MSL) forested site to a lower elevation (1,098 m MSL), agricultural monitoring site. Note difference in scales of vertical axes, $1 \mathrm{ppb}=1 \mathrm{nl} / \mathrm{liter}$ or $\sim 1.96 \mu \mathrm{g} / \mathrm{m}^{3}$ (Krupa and Kickert [24], with kind permission from Kluwer Academic Publishers).
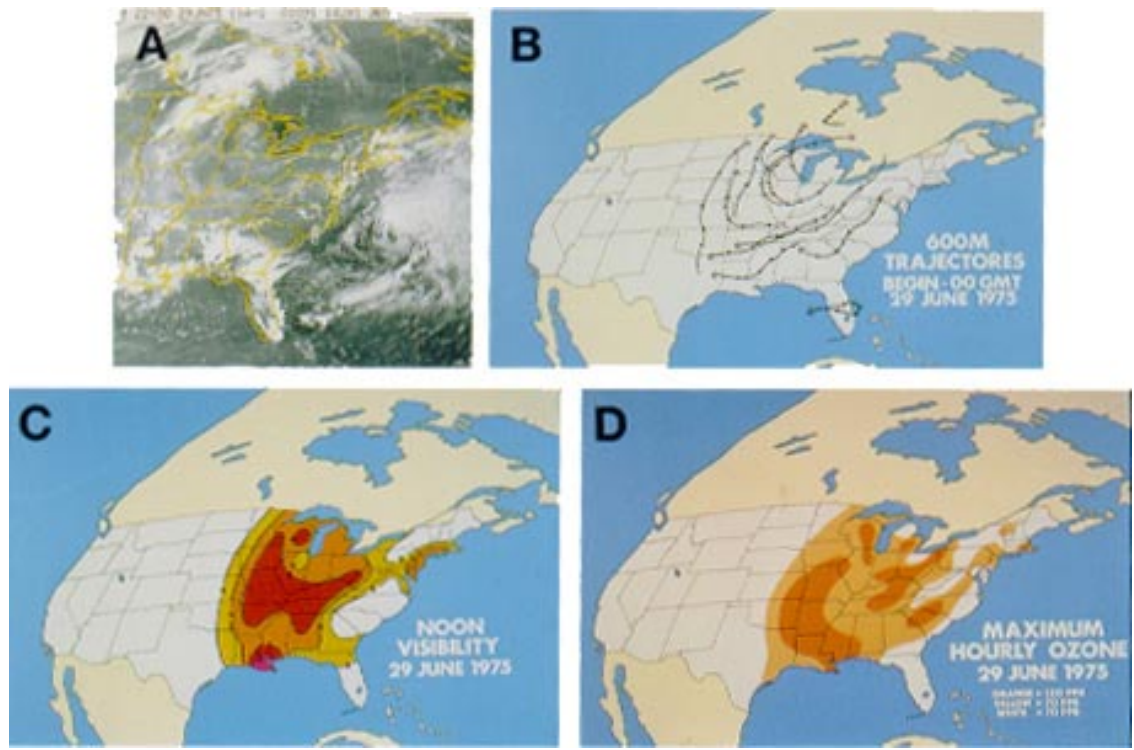

Fig. 3. A, Satellite photograph showing clockwise movement of pollutant clouds from northeast through central United States into eastern half of Minnesota on 29 June 1975. B, Meteorological model showing movement of pollution-containing air parcels across central US into Minnesota on 29 June 1975. Air parcel's path was determined with weather sounding data collected at $600 \mathrm{~m}$ above the ground at various locations in the US. Arrows indicate air parcel location at 12-h intervals, starting at $0.00 \mathrm{~h}$ Greenwich Mean Time (GMT). C, Contours showing number of miles of visibility (1 mile $=1.61 \mathrm{~km}$ ) at various locations in eastern and central United States at noon on 29 June 1975. In the eastern half of Minnesota, visibility ranged from 4 to 8 miles (6.4 to $9.6 \mathrm{~km})$. In the clear area to the northwest, visibility was $>15$ miles (>18 km). Microscopic sulfate particles in the air caused the reduction in visibility. D, Contours showing maximum hourly $\mathrm{O}_{3}$ concentrations in eastern and central United States on 29 June 1975. In the eastern half of Minnesota, maximum hourly $\mathrm{O}_{3}$ concentrations were $>70 \mathrm{ppb}\left(1 \mathrm{ppb}=1 \mathrm{nl} /\right.$ liter or $\left.\sim 1.96 \mu \mathrm{g} / \mathrm{m}^{3}\right)$. During this episode, long range air pollutant transport brought $\mathrm{O}_{3}$ and microscopic sulfate particles together into Minnesota. Two days later, sensitive plant species showed symptoms of $\mathrm{O}_{3}$ injury (Krupa et al. [25]). atmosphere, $\mathrm{O}_{3}$ concentrations increase rapidly between 1200 and $1500 \mathrm{~h}$, when the intensity of solar radiation is at a maximum and the $\mathrm{NO}_{2}: \mathrm{NO}$ ratio is large. The rate of $\mathrm{O}_{3}$ formation may then decline, reaching a steady state during the late afternoon to early evening hours. After that period, $\mathrm{O}_{3}$ concentrations fall as $\mathrm{NO}_{2}$ breakdown diminishes and as fresh emissions of $\mathrm{NO}$ deplete the $\mathrm{O}_{3}$. This daily pattern is quite different at high elevations (in general, above approximately $1,500 \mathrm{~m}$ from the surface or above the so-called mixed layer of the atmosphere), where $\mathrm{O}_{3}$ concentrations remain relatively steady through day and night. At that altitude, there is an $\mathrm{O}_{3}$ reservoir, and destruction of that $\mathrm{O}_{3}$ by the surface is insufficient to produce the type of daily patterns observed at lower elevations (Fig. 2).

During the growing season, stagnant air masses, varying in duration from one to several days, will result in high surface $\mathrm{O}_{3}$ concentrations on a regional scale. Thus, crops and forests are exposed, for a few hours to days, to relatively high $\mathrm{O}_{3}$ concentrations (e.g., >80 nl/liter), with other periods of relatively low concentrations (e.g., <40 nl/liter). The average lifetime of $\mathrm{O}_{3}$ is about $16 \mathrm{~h}$, and once produced, it can be transported long distances to rural agricultural and forested areas (Fig. 3). Thus surface level $\mathrm{O}_{3}$ is an inter-regional (in the eastern United States, California) and even a continental (Europe) scale problem. Table 1 provides a comparison of maximum daily $\mathrm{O}_{3}$ concentrations measured in different regions.

\section{Toxicity to Plants}

Plants are subjected to acute and chronic exposures of ground-level $\mathrm{O}_{3}$. An acute exposure consists of relatively high $\mathrm{O}_{3}$ concentrations (e.g., >80 nl/liter) from a few consecutive hours to days. In comparison, a chronic exposure consists of relatively low $\mathrm{O}_{3}$ concentrations (e.g., <40 $\mathrm{nl} /$ liter) for the entire life of a plant, with periodic intermittent or random episodes of high concentrations. Both acute and chronic $\mathrm{O}_{3}$ exposures can result in symptoms of foliar injury on sensitive plants (Table 2, Fig. 4A to D and 5A to D).

Plant response to $\mathrm{O}_{3}$ varies with the genus, species, cultivar or variety, and geno-

Table 1. Typical summertime daily maximum surface level $\mathrm{O}_{3}$ concentrations $^{\mathrm{a}}$

\begin{tabular}{lc}
\hline Region & $\mathbf{O}_{\mathbf{3}}, \mathbf{n l} /$ liter $^{\mathbf{b}}$ \\
\hline I. Urban-suburban & $100-400$ \\
II. Rural & $50-120$ \\
III. Remote tropical forest & $20-40$ \\
IV. Remote marine & $20-40$ \\
\hline a Source: Modified from National Re- & Ne \\
bearch Council, US (34). \\
b 1 nl/liter $=1 \mathrm{ppb}$ or $\sim 2 \mu \mathrm{g} / \mathrm{m}^{3}$.
\end{tabular}



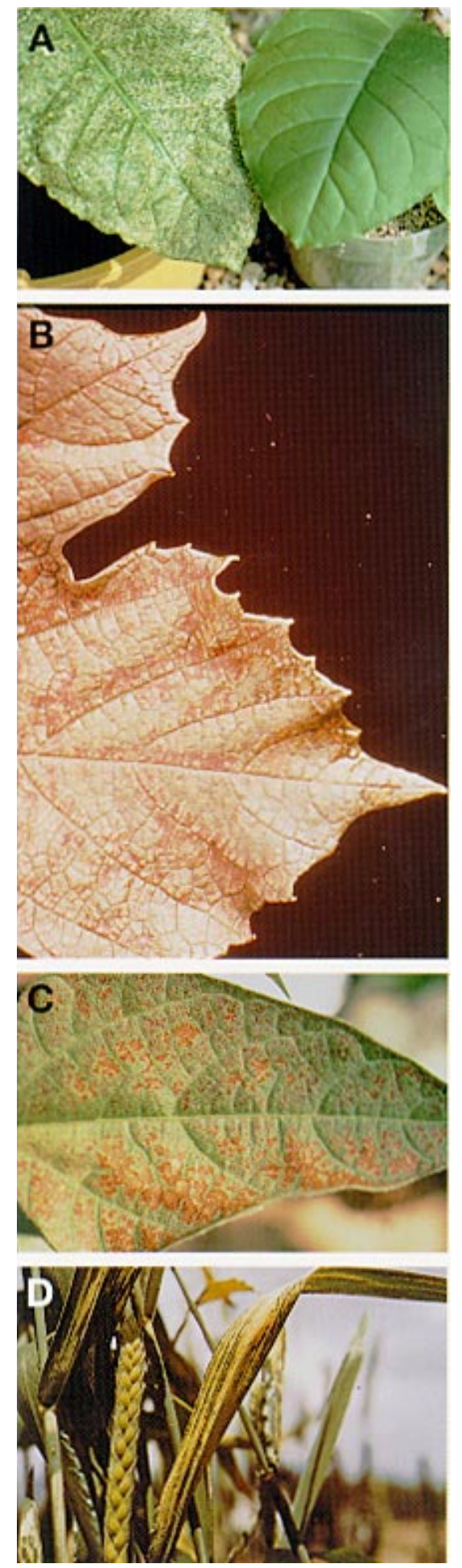

Fig. 4. Ozone-induced symptoms of foliar injury: A, close-up view of a healthy tobacco (Nicotiana tabacum) leaf (right) and a leaf showing flecking (left); B, part of grape (Vitis vinifera) leaf showing purple stippling; $\mathrm{C}$, pinto bean (Phaseolus vulgaris) leaf showing bifacial necrosis between larger veins; $D$, wheat (Triticum aestivum) leaf blade showing vertical, chlorotic streaks between larger veins (A, C, D, Krupa et al. [26], B, courtesy of the late F. A. Wood).
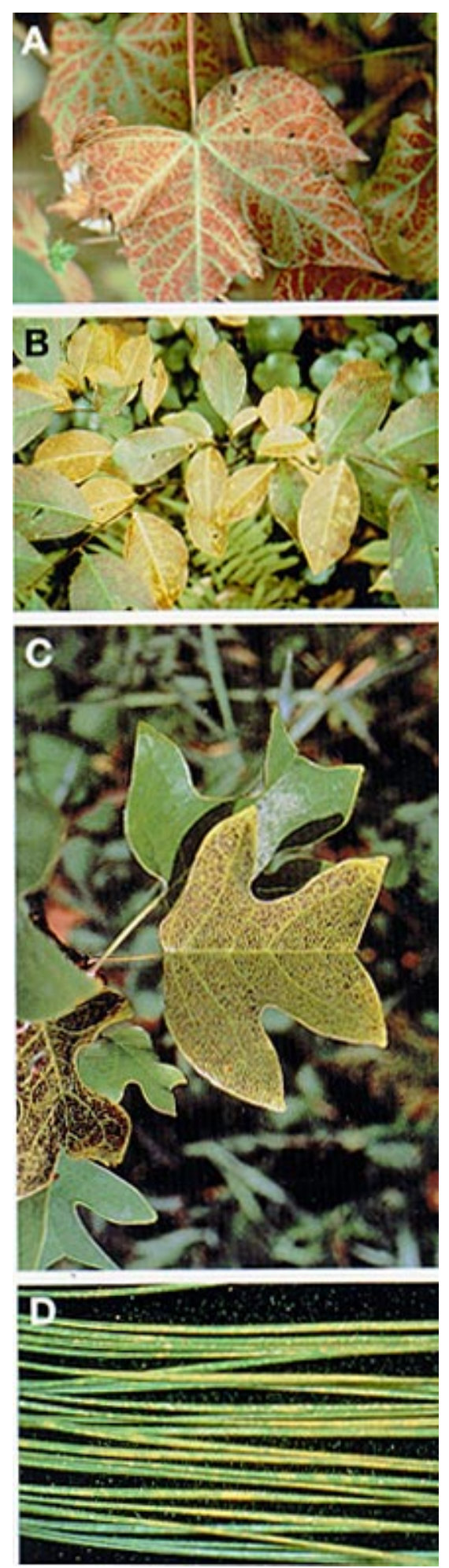

Fig. 5. Ozone-induced symptoms of foliar injury: A, close-up view of cotton (Gossypium hirsutum) leaf showing chronic response, premature senescence, and purple pigmentation in the interveinal areas; $B$, upper surface purple, stippling on black cherry (Prunus serotina); C, yellow poplar (Liriodendron tulipifera) showing upper surface purple stipple; D, close-up view of chlorotic mottle on needles of Ponderosa pine (Pinus ponderosa) (Krupa et al. [26]). type. Nevertheless, several plant species have been characterized for their development of $\mathrm{O}_{3}$ injury symptoms and are used as biological indicators (Table 3 ) to assess relative $\mathrm{O}_{3}$ exposures at various geographic locations. Among all indicator plants, tobacco (Nicotiana tabacum L.) cv. Bel-W3 $\left(\mathrm{O}_{3}\right.$-sensitive $)$ and cv. Bel-B $\left(\mathrm{O}_{3}\right.$-tolerant $)$ are the best described and the most commonly used worldwide. For example, some 20,000 residents voluntarily grew the two tobacco cultivars in pots, as part of a biomonitoring network in the British Isles during the 1990s, to assist in mapping the geographic distribution of the occurrences of phytotoxic concentrations of $\mathrm{O}_{3}$ in the United Kingdom (17). However, foliar injury cannot always be directly related to yield losses. Therefore, more recently, a white clover (Trifolium repens L.) indicator system (A. S. Heagle and J. E. Miller, USDA, ARS, North Carolina State University, Raleigh, http://www.ncl.ac.uk/airweb/ ozone/clover0.htm), consisting of two specific clones that differ in their biomass responses (yield) to ambient levels of $\mathrm{O}_{3}$, is being used in the United States and Europe (Centre for Ecology and Hydrology, http://icpvegetation.ceh.ac.uk) to measure the relative effects. This is to indicate geographic areas where plants may suffer adverse growth and yield effects due to ambient $\mathrm{O}_{3}$ stress, with or without foliar injury symptoms. These studies have shown, for example, that the biomass of the $\mathrm{O}_{3}$-sensitive clover clone can be reduced by $25 \%$ on Long Island, NY, and by at least $50 \%$ in California $(16,29)$.

\section{How Ozone Affects Plants}

Ozone is deposited from the atmosphere onto plant canopies by diffusion and enters the leaf through stomata. Environmental, biological, and cultural (e.g., irrigation) factors that promote stomatal opening increase the risk of $\mathrm{O}_{3}$ injury to plants (26). Ozone causes negative effects on a number of plant processes, including photosynthesis, water use efficiency, rate of senescence, dry matter production, flowering, pollen tube extension, and yield (22).

While many physiological functions necessary for growth and reproduction are impaired by $\mathrm{O}_{3}$, specific cellular sites that undergo damage are not completely known. For example, photosynthetic activity can be reduced by decreasing stomatal opening and restricting $\mathrm{CO}_{2}$ uptake, by diminishing energy production in the photosystems, or by decreasing $\mathrm{CO}_{2}$ assimilation. Although $\mathrm{O}_{3}$ is known to cause stomatal closure, that effect appears to be secondary, since electrophysiological studies have demonstrated that $\mathrm{O}_{3}$ affects stomatal opening only indirectly (46). The amount of active carboxylating (acceptance of $\mathrm{CO}_{2}$ ) enzyme, RUBISCO (ribulose biphosphate carboxylase), can be reduced by $\mathrm{O}_{3}(8)$. The effects on RUBISCO can be either by direct oxidation (36) or through 
suppression of messenger RNA (ribonucleic acid) production (38). Chlorophyll fluorescence measurements have shown that $\mathrm{O}_{3}$ can damage various components of the light-harvesting complex in the chloroplasts. In sensitive plants, foliar injury reduces the number of functional complexes, diminishing the plant's capability to utilize sunlight for photosynthesis (14). At lower concentrations, or in tolerant plants, $\mathrm{O}_{3}$ can interfere with the production of electrons, limiting the energy available to "fix" $\mathrm{CO}_{2}(15)$. Although $\mathrm{O}_{3}$ can affect these various functions in the photosynthetic pathway, the sensitivities of the different components, the sequence of events occurring, and the specific sites of injury are yet to be identified. In addition to its effect on shoots, $\mathrm{O}_{3}$ is known to adversely affect carbon flow to the roots and consequently their biology and biomass (Fig. 6).

\section{How Some Plants Tolerate Ozone}

It is generally accepted that $\mathrm{O}_{3}$ does not persist in the intercellular spaces of the leaf. Rather, organic radicals and various reactive forms of oxygen are generated through $\mathrm{O}_{3}$ decomposition and interactions with cell components (37). These oxidizing compounds damage proteins and membranes, leading to impaired physiological function and cell death. Acute $\mathrm{O}_{3}$ injury in sensitive genotypes, usually seen as development of foliar lesions, resembles the hypersensitive response (HR) of plants to pathogen attack. An oxidative burst occurs as the initial reaction to both $\mathrm{O}_{3}$ exposure and pathogen assault, and similar signal molecules have been implicated in induction of the $\mathrm{HR}$ and $\mathrm{O}_{3}$ injury $(40,44)$. In $\mathrm{O}_{3}$-tolerant genotypes, either the oxidative burst is suppressed (45) or oxidative damage is highly localized (21), thereby restricting the extent of foliar lesions.

Since the signal pathways that mediate the response of plants to $\mathrm{O}_{3}$ and pathogens appear to have some common features, our understanding of mechanisms that limit $\mathrm{O}_{3}$ injury could benefit from studies on the molecular aspects of plant-pathogen inter-

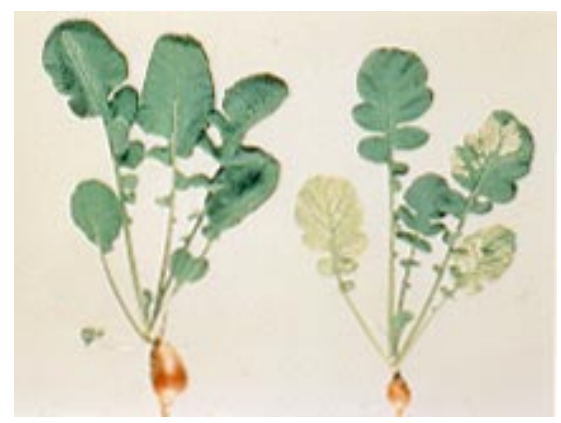

Fig. 6. Left: radish (Raphanus sativus) plant grown in filtered air; right: plant grown in unfiltered air containing $\mathrm{O}_{3}$ and other photochemical oxidants (Courtesy of H. E. Heggestad). actions (41). The plant antioxidant system, which scavenges naturally occurring reactive oxygen compounds, could function as a primary mechanism to alleviate the oxidative burden resulting from $\mathrm{O}_{3}$ exposure. The ascorbate (vitamin C)-glutathione (an amino acid tripeptide) cycle has been the most intensively studied, and generally there is a positive correlation of $\mathrm{O}_{3}$ tolerance with levels of antioxidants and antioxidant enzyme activities (5). For example, mutants that are deficient in vitamin $\mathrm{C}$ are very sensitive to $\mathrm{O}_{3}(6)$, as are plants that have been genetically manipulated to produce less ascorbate peroxidase, an enzyme that uses vitamin $\mathrm{C}$ to detoxify hydrogen peroxide (35). Transgenic plants that have been engineered to overproduce ascorbateglutathione antioxidant enzymes have pro- vided mixed results regarding $\mathrm{O}_{3}$ tolerance, depending upon the species, the cellular compartment in which the enzyme is expressed, and the isozyme (distinct forms of an enzyme, but with identical function) chosen (32).

Numerous other antioxidant compounds are found in plants, and their role in $\mathrm{O}_{3}$ tolerance needs to be further explored. In addition to signaling processes and biochemical protective mechanisms, plants may express differential tolerance depending upon the rate of influx of $\mathrm{O}_{3}$ into the leaf interior. Uptake may be affected by stomatal density or by guard cell response to oxidative conditions. It appears that $\mathrm{O}_{3}$ does not directly affect stomatal closure (46), but acts indirectly, perhaps by influencing $\mathrm{CO}_{2}$ "fixation" or altering hormone

Table 2. Common symptoms of $\mathrm{O}_{3}$-induced foliar injury ${ }^{\mathrm{a}}$

\begin{tabular}{|c|c|}
\hline Acute injury & Chronic injury \\
\hline \multicolumn{2}{|l|}{ Broad-leaved plants } \\
\hline $\begin{array}{l}\text { Bleaching (unifacial/upper surface or bifa - } \\
\text { cial): small unpigmented necrotic spots or } \\
\text { more general upper surface bleaching. Pali- } \\
\text { sade cells and, when injury is more severe, } \\
\text { upper epidermal cells collapse and become } \\
\text { bleached. }\end{array}$ & $\begin{array}{l}\text { Pigmentation (bronzing): leaves turn red- } \\
\text { brown to brown as phenolic pigments ac- } \\
\text { cumulate. }\end{array}$ \\
\hline $\begin{array}{l}\text { Flecking: small necrotic areas due to death of } \\
\text { palisade cells, metallic or brown, fading to } \\
\text { tan, gray, or white. }\end{array}$ & $\begin{array}{l}\text { Chlorosis: may result from nongreen pig - } \\
\text { mentation or may occur alone as chloro - } \\
\text { phyll breaksdown. }\end{array}$ \\
\hline $\begin{array}{l}\text { Stippling: tiny punctate spots where a few } \\
\text { palisade cells are dead or injured, may be } \\
\text { white, black, red, or red-purple. }\end{array}$ & $\begin{array}{l}\text { Premature senescence: early loss of leaves, } \\
\text { flowers or fruit. }\end{array}$ \\
\hline \multicolumn{2}{|l|}{$\begin{array}{l}\text { Bifacial necrosis: when the entire tissue } \\
\text { through the leaf is killed, bifacial, dead ar - } \\
\text { eas develop ranging in color from white to } \\
\text { dark orange-red. While small veins are usu- } \\
\text { ally killed along with the other tissue, larger } \\
\text { veins frequently survive. }\end{array}$} \\
\hline \multicolumn{2}{|l|}{ Conifers } \\
\hline $\begin{array}{l}\text { Banding: clear bands of chlorotic tissue on } \\
\text { semimature needle tissue following } \mathrm{O}_{3} \text { epi- } \\
\text { sodes. }\end{array}$ & $\begin{array}{l}\text { Flecking and mottling: flecking is the ear - } \\
\text { liest symptom on the older needles of } \\
\text { conifers. Mottling is generally associated } \\
\text { with diffuse chlorotic areas interspersed } \\
\text { with green tissue on first-year needles. }\end{array}$ \\
\hline $\begin{array}{l}\text { Tipburn: characterized by dying tips of } \\
\text { young elongating needles. At first reddish } \\
\text { brown in color, later turning brown, injury } \\
\text { spreading from the tip downward. }\end{array}$ & Premature senescence: early loss of needles. \\
\hline
\end{tabular}

Table 3. List of some plant species that are sensitive to $\mathrm{O}_{3}$ and used as indicator plants

\begin{tabular}{llll}
\hline Common name & Latin name & Common name & Latin name \\
\hline Annual blue grass & Poa annua & Morning glory & Pharbitis nil= Ipomoea spp. \\
Bean & Phaseolus vulgaris & & Ipomoea purpurea \\
Blackberry & Rubus spp. & Quaking aspen & Populus tremuloides \\
Black cherry & Prunus serotina & Sassafras & Sassafras albidum \\
Clover & Trifolium repens & Spinach & Spinacea oleracea \\
Green ash & Fraxinus pennsylvanica & Tobacco & Nicotiana tabacum \\
Milkweed & Asclepias syriaca & Yellow poplar & Liriodendron tulipifera \\
& & White ash & Fraxinus americana \\
\hline
\end{tabular}

a Source: Modified from Krupa et al. (26). 
levels. The role of stomates in influencing $\mathrm{O}_{3}$ tolerance is not fully characterized at present.

\section{Ozone and Plant Disease}

Although ozone can influence the development of plant diseases (28), the underlying processes are not well understood. In general, $\mathrm{O}_{3}$ can decrease the incidence of diseases caused by obligate parasites, while increasing the problems associated with facultative parasites (Table 4). Ozone is unlikely to have direct effects on fungal pathogens; rather, the effects are host plant mediated. Conversely, occurrence of diseases can alter the foliar responses to $\mathrm{O}_{3}$. Much of this knowledge is based on empirical field observations and experimental studies conducted in controlled environment, greenhouse, or field exposure chambers. There is no information on the joint effects of $\mathrm{O}_{3}$ and disease on plant growth and yield.

\section{Effect on Crops and Trees}

Numerous investigators have shown that chronic, whole growth season or whole life cycle exposures to $\mathrm{O}_{3}$ can result in losses of marketable yield in crops (Fig. 7A and $\mathrm{B})$ and reductions in growth and productivity of tree species (47). The chronic effects of $\mathrm{O}_{3}$ on tree populations have consequences to aesthetic and recreational aspects of our national forests and national parks and are of much concern to governmental agencies. In this context, the forests of the San Bernardino Mountains of Southern California serve as a classic illustration of the long-term impact of ambient $\mathrm{O}_{3}$ on a forest ecosystem (31) (Fig. 8).

Table 4. Some examples of the effects of $\mathrm{O}_{3}$ on plant diseases ${ }^{\mathrm{a}}$

\begin{tabular}{|c|c|c|}
\hline Pathogen & Host plant & Effect on disease $^{b}$ \\
\hline \multicolumn{3}{|l|}{ Fungi - Obligate biotrophs } \\
\hline Puccinia coronata & Oats & Reduced growth of uredia \\
\hline Puccinia graminis f. sp. tritici & Wheat & $\begin{array}{l}\text { Decreased hyphal growth and uredio- } \\
\text { spore production on } \mathrm{O}_{3} \text {-injured leaves }\end{array}$ \\
\hline Erysiphe graminis f. sp. hordei & Barley & $\begin{array}{l}\text { Reduced rate of infection if exposed to } \\
\text { sufficient } \mathrm{O}_{3} \text { during incubation; en - } \\
\text { hanced colony size when infection is } \\
\text { established }\end{array}$ \\
\hline
\end{tabular}

Fungi - Necrotrophs

\begin{tabular}{|c|c|c|}
\hline Drechslera sorokiniana & Wheat & Increased percentage of diseased leaf area \\
\hline Botrytis cinerea & Potato & Infection only on $\mathrm{O}_{3}$ injured leaves \\
\hline Lophodermium sp. & Pine & Increased severity of needle blight \\
\hline \multicolumn{3}{|l|}{ Bacteria } \\
\hline Pseudomonas glycinea & Soybean & Reduced number of lesions \\
\hline Xanthomonas alfalfae & Alfalfa & Reduced severity of bacterial infection \\
\hline Xanthomonas fragariae & Wild strawberry & Reduced number of lesions \\
\hline
\end{tabular}

a Source: Modified from Manning and von Tiedemann (28).

b Observed effect on disease was dependent upon whether plants were exposed to sufficient dose of $\mathrm{O}_{3}$ before or after inoculation with the pathogen.

Reductions in growth and yield can occur with or without symptoms of $\mathrm{O}_{3}$-induced foliar injury. Nevertheless, based on numerous experimental studies, it has been estimated that ambient $\mathrm{O}_{3}$ exposure causes $\$ 0.8$ billion annually in crop loss in the United States (47). A similar estimate is not available for tree species, but the adverse effects of $\mathrm{O}_{3}$ on our national parks and forests are not in doubt $(4,30)$.

\section{Alteration of Plant Community Structure and Biodiversity}

Several plant species in U.S. national parks are known to exhibit foliar injury to ambient $\mathrm{O}_{3}$ exposure. For example, in Acadia National Park in Maine, black cherry, quaking aspen, white ash (Fraxinus americana L.), jack pine (Pinus banksiana Lamb.), big-leaf aster (Aster macrophyllus L.), and spreading dogbane (Apocynum androsaemifolium L.) are sensitive. Similarly, widespread $\mathrm{O}_{3}$-induced foliar injury has been observed on the native black cherry and tall milkweed (Asclepias exaltata L.) in the Great Smoky Mountains National Park. How these foliar responses translate to other issues such as competitive sustainability of a given species within the native plant communities are not fully understood at the present time.

Nevertheless, tests conducted to determine the effects of $\mathrm{O}_{3}$ on the competitive relationships between native plants showed, for example, that the rate of blackberry:broom-sedge (Andropogon virginicus L.) litter decomposition was reduced with increasing $\mathrm{O}_{3}$ concentrations, with implications for altering nutrient cycling and biological diversity (2).

One aspect of assessing biological diversity is species fitness or reproductive capacity. For example, experimental $\mathrm{O}_{3}$ exposures reduced growth and flowering of

\section{Characterization and Mechanisms of Plant Responses to $\mathrm{O}_{3}$}

The agricultural experiment stations of the land grant universities have supported $\mathrm{O}_{3}$ exposure-plant effects research through NE (northeast)-176 and its predecessors, representing the longest multistate or institutional research and outreach project in the United States. Although the U.S. Environmental Protection Agency (EPA) has maintained large-scale, in-house and cooperative research programs with other governmental agencies, NE-176 represents the best-sustained effort through continued commitment of the agricultural experiment stations.

This multistate project began as Northeast Regional Project 56 (NE-56) in 1966, with nine states (extending from Maine to North Carolina and the Mid-Atlantic region) participating (20). The principal aim of the project was to measure atmospheric oxidant $\left(\mathrm{O}_{3}\right)$ concentrations at different locations within the region during the growing season and observe foliar injury to indicator plants (tobacco sensitive cv. Bel-W3 and tolerant cv. Bel-B). This was to determine the frequency of occurrence and distribution of oxidants and phytotoxicity of the atmosphere. By the early 1970s, it was well accepted that ambient $\mathrm{O}_{3}$ was an inter-regional problem of concern for crop and forest productivity. Thus in 1972, after reaching its initial goal, NE-56 ceased to function. Subsequently project scientists expanded their objectives beyond the use of indicator plants to include the effects of $\mathrm{O}_{3}$ on plant physiological processes, growth, and yield. After a series of 5-year cycles of study, the project was designated NE-176 in 1990.

Current research activities in NE-176 include studies on the biochemical and molecular mechanisms of $\mathrm{O}_{3}$ injury and sensitivity or tolerance in plants; impact of $\mathrm{O}_{3}$ on carbon allocation, carbon/nitrogen relationships, and secondary metabolism as they affect pathogen and pest relations, decomposition rates, and nutrient cycling; joint effects of $\mathrm{O}_{3}$ with other factors influencing growth and yield, such as increasing $\mathrm{CO}_{2}$ concentrations, and changes in temperature and water availability; yield responses of crops and growth responses of trees, and effects of $\mathrm{O}_{3}$ on plant community structure and species diversity. Additional research activities relate to modeling cause-effect relationships, including ecosystem processes. Overall, these efforts are continuing to serve target audiences ranging from individual homeowners to large industrial corporations and state and federal governmental agencies (Table 5). 
the butterfly bush (Buddleia spp.) (9). Similarly, exposures to $\mathrm{O}_{3}$ reduced flowers and fruits in spreading dogbane. A very important finding here was that foliar injury was not necessarily required to elicit negative effects on sexual reproduction and thus changes in biological diversity (3).

\section{A Look to the Future}

Ozone is a "criteria air pollutant." This designation is based on the fact that there are documented adverse effects of $\mathrm{O}_{3}$ on people, plants, or materials at concentrations, or approaching those, found in polluted air. There are air quality standards (U.S.), air quality objectives (Canada), and critical levels (Commission of the European Communities) for $\mathrm{O}_{3}$ to protect vegetation against adverse effects (27). In the United States, Congressional mandate requires the Environmental Protection Agency (EPA) to review all available scientific literature and revise air quality standards where required, for approval by the Congress, once every 5 years. At present, the tentative $\mathrm{O}_{3}$ standard in the United States is an 8-h running average of 80 $\mathrm{nl} /$ liter, not to be exceeded more than twice in three consecutive years. This standard is tentative because of a pending decision regarding court challenges by industry against the EPA's legislative authority within the Clean Air Act of the U.S. Congress (American Trucking Associations, ATA Inc. versus EPA). This case is now in the Supreme Court.

Leaving aside the judicial controversy, much of our knowledge of the effects of $\mathrm{O}_{3}$ on plants is derived from controlled environment or field chamber exposure studies. Plants in the ambient environment do not grow in chambers. Although chamber studies have the value of providing us with a basic understanding of cause and effect, results from such studies cannot be directly extrapolated to the chamberless ambient environment, where cost-benefit policies are involved. There is a significant need to conduct chamberless field studies to determine the effects of ambient levels of $\mathrm{O}_{3}$ on plant growth, productivity, and species fitness, in the context of biological diversity. The emphasis has been on univariate studies $\left(\mathrm{O}_{3}\right.$ only as the cause of an effect), but there is a need to address the $\mathrm{O}_{3}$ issue in the context of the presence of other air pollutants (47) and the incidence of pathogens $(28,47)$ and insect pests $(11,47)$. The resulting joint effects can be additive, more than additive, or less than additive (47). Because of its complexity, no studies have directly addressed this overall question. The subject becomes much more complex when we try to integrate $\mathrm{O}_{3}$ and climate change (increasing $\mathrm{CO}_{2}$ concentrations, changes in temperature and precipitation patterns, etc.). This holistic research is a prime target for plant disease epidemiologists. In all of these cases, the limiting factor is the integration of the science spanning multiple disciplines.

During the last decades, as urban centers and consequent highway traffic have continued to grow in the United States and elsewhere, so have the ground level $\mathrm{O}_{3}$ concentrations. The National Research

Table 5. NE-176: Characterization and mechanisms of plant responses to ozone $\left(\mathrm{O}_{3}\right)$ in the northeastern United States

\begin{tabular}{|c|c|c|}
\hline Participating institution ${ }^{\mathbf{a}}$ & Target audience & Type of outcome \\
\hline $\begin{array}{l}\text { 1. NE agricultural experiment } \\
\text { stations: } \\
\text { MA, University of Massachu- } \\
\text { setts; MD, University of } \\
\text { Maryland; NJ, Rutgers Uni- } \\
\text { versity; NY, Cornell Univer- } \\
\text { sity/Long Island; PA, Penn- } \\
\text { sylvania State University. } \\
\text { 2. Other agricultural experi- } \\
\text { ment stations: } \\
\text { AL, Auburn University; CA, } \\
\text { University of California-Riv- } \\
\text { erside; MN, University of Min- } \\
\text { nesota; VA, Virginia Polytech- } \\
\text { nic Institute \& State University. } \\
\text { 3. Other institutions: } \\
\text { CA, USFS, Riverside; MD, } \\
\text { USDA/ARS-BARC, Beltsville; } \\
\text { NC, USDA/ARS-North Carolina } \\
\text { State University; NY, Boyce } \\
\text { Thompson Institute at Cornell } \\
\text { University; OR, US EPA. }\end{array}$ & $\begin{array}{l}\text { (a) EPA; (b) NASA; (c) man- } \\
\text { agers of national parks, class I } \\
\text { wilderness areas and forested } \\
\text { land; (d) managers of urban } \\
\text { public park and recreational } \\
\text { lands; (e) county extension \& } \\
\text { outreach educators; (f) home } \\
\text { and master gardeners; (g) ar- } \\
\text { borists, landscape, and nursery } \\
\text { managers; (h) private plant } \\
\text { disease and pest con sultants; } \\
\text { (i) regional energy and chemi- } \\
\text { cal industry; (j) provincial en- } \\
\text { vironmental regulators; (k) } \\
\text { scientists and environmental } \\
\text { regulators in developing } \\
\text { countries (e.g., Mexico, East- } \\
\text { ern Block countries), includ- } \\
\text { ing undergraduate and gradu- } \\
\text { ate students and faculty } \\
\text { members in academe; (l) envi- } \\
\text { ronmental conservation } \\
\text { groups; (m) crop breeders and } \\
\text { (n) seed companiesF. }\end{array}$ & $\begin{array}{l}\text { (a) Application of the re- } \\
\text { sults in developing fed- } \\
\text { eral air quality standards } \\
\text { to protect crops, forests } \\
\text { and native plants; (b) } \\
\text { breeding tolerant crop } \\
\text { cultivars for seed pro- } \\
\text { duction and use; (c) } \\
\text { identification of } \mathrm{O}_{3} \text { tol- } \\
\text { erant materials for use in } \\
\text { gardens, urban land- } \\
\text { scapes and parks; (d) in- } \\
\text { creased environmental } \\
\text { awareness through out- } \\
\text { reach; (e) improved } \\
\text { management of national } \\
\text { parks and protected eco- } \\
\text { systems; (f) early detec- } \\
\text { tion of ecosystems under } \\
\mathrm{O}_{3} \text { stress for developing } \\
\text { mitigation policies; (g) } \\
\text { sharing knowledge } \\
\text { through international } \\
\text { education and coopera- } \\
\text { tive research. }\end{array}$ \\
\hline
\end{tabular}

a Additional institutions joining are: IA - Iowa State University, Ames; NB, Canada - CFS, Fredericton; and NC - Appalachian State University, Boone.
Council published an authoritative document in 1992 called "Rethinking the ozone problem in urban and regional air pollution" (34). Most recently, a number of state-of-the-science papers have been published (33). Alternative transportation strategies such as mass transit and the use of fuel other than gasoline (a major source of $\mathrm{O}_{3}$ precursor pollutants) in automobiles may provide some relief in the United

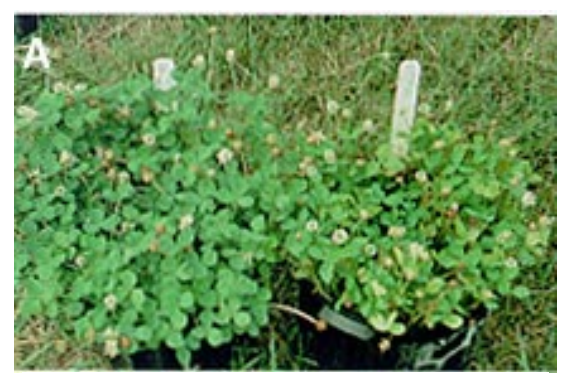

B

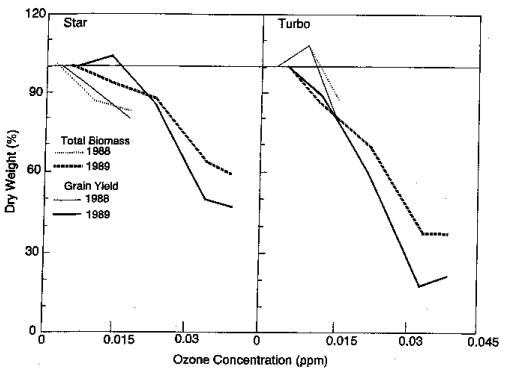

Fig. 7. A, Differential biomass responses of tolerant (left) and sensitive (right) white clover (Trifolium repens) clones to ambient $\mathrm{O}_{3}$ exposures in Massachusetts (Courtesy of W. J. Manning); B, yield responses of two different cultivars of wheat subjected to chronic $\mathrm{O}_{3}$ exposure (Adaros et al. [1]).

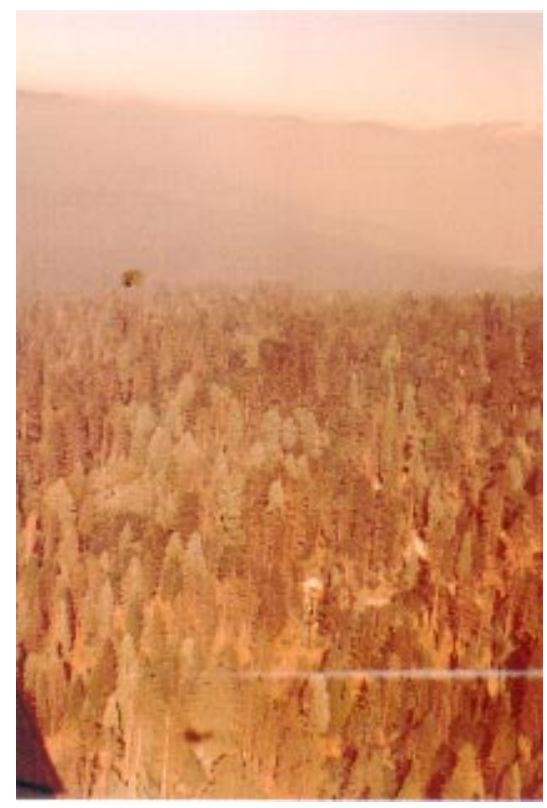

Fig. 8. Stressed conifer ecosystem of the San Bernardino National Forest, CA, exposed to smog $\left(\mathrm{O}_{3}\right)$ from Los Angeles (Courtesy of P. R. Miller). 
States and other developed countries, perhaps some 20 years hence (42). Nevertheless, $\mathrm{O}_{3}$ is and will continue to be a growing problem in developing countries. Already Mexico City, New Delhi, and Beijing are among urban centers generating significant ground level $\mathrm{O}_{3}$ concentrations. Hemispheric $\mathrm{O}_{3}$ problems are being created by forest fires and burning clear cut for land reclamation in Central and South America and Southeast Asia. Forest fires and biomass burning result in emissions of the precursor compounds for $\mathrm{O}_{3}$ formation.

Our current understanding of the effects of $\mathrm{O}_{3}$ on plants is almost entirely based on studies conducted with temperate species and environmental conditions. We have very little knowledge of crop and forest responses in the Southern Hemisphere. This is also the part of the world where the rate of population growth has been the most between 1960 and 1990 (13). Thus, given the instability of sociopolitical and economic issues, sustaining global populations will require a global perspective of ambient $\mathrm{O}_{3}$, air quality in general, including climate change $\left(\mathrm{O}_{3}\right.$ is a part of that process), and food, fiber, and timber production.

\section{Acknowledgments}

The authors of this paper and the other participants in the USDA/Multi-State Project NE-176 thank their individual Agricultural Experiment Stations and corresponding agencies for their continued support of the project research activities. We thank the individual Agricultural Experiment Station directors, who have served over the years as the administrative advisors to NE-176.

\section{Literature Cited}

1. Adaros, G., Weigel, H. J., and Jäger, H.-J. 1991. Die Wirkung von ozon auf wachstumsund Ertragsparameter zweier. Sommerweizensorten (Triticum aestivum L.). Z. Pflanzenkrankh. Pflanzenschutz 98:113-124.

2. Barbo, D. N., Chappelka, A. H., Somers, G. L., Miller-Goodman, M. S., and Stolte, K. 1998. Diversity of an early successional plant community as influenced by ozone. New Phytol. 138:653-662.

3. Bergweiler, C. J., and Manning, W. J. 1999. Inhibition of flowering and reproductive suc- cess in spreading dogbane (Apocynum androsaemifolium) by exposure to ambient ozone. Environ. Pollut. 105:333-339.

4. Chappelka, A. H., and Samuelson, L. J. 1998. Ambient ozone effects on forest trees of the eastern United States: A review. New Phytol. 139: 91-108.

5. Conklin, P. L., and Last, R. L. 1995. Differential accumulation of antioxidant mRNAs in Arabidopsis thaliana exposed to ozone. Plant Physiol. 109:203-212.

6. Conklin, P. L., Williams, E. H., and Last, R. L. 1996. Environmental stress sensitivity of an ascorbic acid-deficient Arabidopsis mutant. Proc. Natl. Acad. Sci. USA 93:99709974

7. Daines, R. H., Leone, I. A., and Brennan, E G. 1960. Air pollution as it affects agriculture in New Jersey. Bull. 794. New Jersey Agricultural Experiment Station, 1960. Rutgers, NJ. p. 14

8. Enyedi, A. J., Eckardt, N. A., and Pell, E. J 1992. Activity of ribulose bisphosphate carboxylase/oxygenase from potato cultivars with differential response to ozone stress. New Phytol. 122:493-500.

9. Findley, D. L., Keever, G. J., Chappelka, A H., Gilliam, C. H., and Eakes, D. J. 1997. Differential response of buddleia (Buddleia davidii Franch.) to ozone. Environ. Pollut.

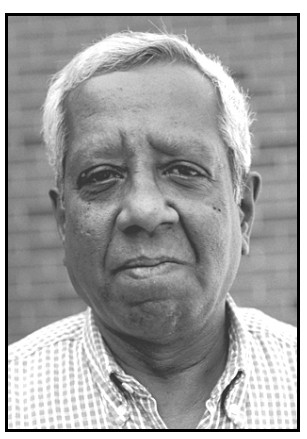

Sagar Krupa

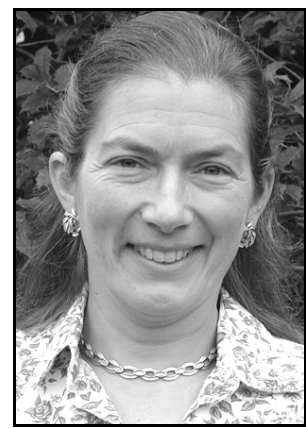

Margaret Tuttle McGrath

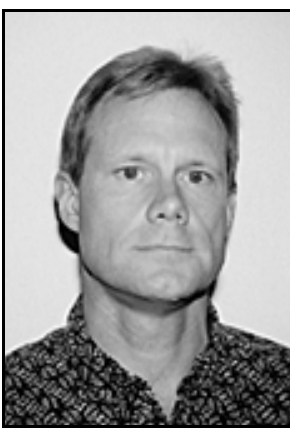

Christian P. Andersen

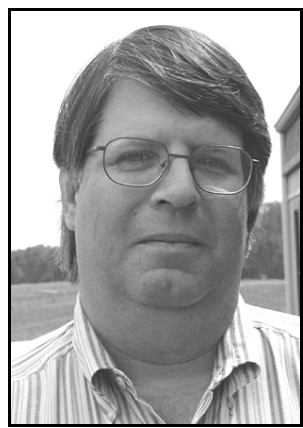

Fitzgerald L. Booker
Dr. Krupa is a professor of plant pathology at the University of Minnesota with research and undergraduate teaching (agriculture-environmental sciences major) responsibilities in the area of air pollution, global climate change, and their effects on agriculture. He received his Fil.Dr. (Docent) from the University of Uppsala, Sweden. His research interests are modeling the interactions between atmospheric processes and crop responses, with emphasis on $\mathrm{O}_{3}$. He is a Fellow of the Air \& Waste Management Association (the second plant scientist to be given that honor) and was a Distinguished International Visiting Professor of the Mexican Academy of Sciences in 1997 (the first scientist in agriculture to be so recognized). Among others, he has served as a technical consultant to the UN-FAO and the committee on "Protecting the Earth's Atmosphere" of the German Parliament. In addition to his many other books, he is the author of Air Pollution, People and Plants (APS Press, 1997). He is also one of four associate editors to the journal Environmental Pollution and is the chief editor of the book series Developments in Environmental Science (both by Elsevier Science, England).

Dr. McGrath is an associate professor in the Department of Plant Pathology at Cornell University. She received her Ph.D. in plant pathology from Penn State University in 1988. Since 1989, she has been investigating the impact on plant productivity of ambient $\mathrm{O}_{3}$ at the Long Island Horticultural Research and Extension Center in Riverhead, NY. Through her work she has documented that $\mathrm{O}_{3}$ is high enough to affect growth of sensitive plants in the most important agricultural county in New York.
Dr. Andersen is a research plant physiologist with the Environmental Protection Agency in Corvallis, OR. He received his Ph.D. from the University of Minnesota in 1987 and joined the EPA in 1988 after completing a postdoctoral appointment at Oak Ridge National Laboratory in Oak Ridge, TN. Dr. Andersen's research has focused on understanding how stresses such as $\mathrm{O}_{3}$ affect carbon allocation to roots and mycorrhizae, and how these changes influence belowground processes in forested ecosystems. His research has shown that $\mathrm{O}_{3}$ alters physiological processes in roots, leading to changes in soil microbial communities.

Dr. Booker is a plant physiologist at the USDA-ARS Air Quality Research Unit and associate professor in the Department of Crop Science at North Carolina State University. He received his Ph.D. in botany from North Carolina State University in 1988. Since 1989, he has been with the USDA-ARS Air Quality Research Unit and North Carolina State University investigating the effects of UV-B radiation, $\mathrm{O}_{3}$, and elevated $\mathrm{CO}_{2}$ on crop plants. His current research examines the role of stomatal conductance in controlling plant responses to elevated $\mathrm{CO}_{2}$ and $\mathrm{O}_{3}$. In addition, his research interests include the effects of elevated $\mathrm{CO}_{2}, \mathrm{O}_{3}$, and other environmental factors on secondary compounds such as phenolics, lignin, and tannins, and plant decomposition. 
98:105-111.

10. Finlayson-Pitts, B. J., and Pitts, J. N. 1999. Chemistry of the Upper and Lower Atmosphere. Academic Press, New York.

11. Flückiger, W., Braun, S., and Bolsinger, M. 1988. Air pollution: Effect on host plant-insect relationships. Pages 366-380 in: Air Pollution and Plant Metabolism. S. SchulteHostede, N. M. Darrall, L. W. Blank, and A. R. Wellburn, eds. Elsevier Applied Science, London.

12. Fox, C. B. 1873. Ozone and Antozone. J. \& A. Churchill, London.

13. Gommes, R. 1993. Current climate and population constraints on world agriculture. Pages 67-86 in: Agricultural Dimensions of Global Climate Change. H. M. Kaiser and T. E. Drennen, eds. St. Lucie Press, Delray Beach, FL.

14. Guidi, L., Di Cagno, R., and Soldatini, G. F. 2000. Screening of bean cultivars for their response to ozone as evaluated by visible symptoms and leaf chlorophyll fluorescence. Environ. Pollut. 107:349-355.

15. Guidi, L., Nali, C., Ciompi, S., Lorenzini, G., and Soldatini, G. F. 1997. The use of chlorophyll fluorescence and leaf gas exchange as methods for studying the different responses to ozone of two bean cultivars. J. Exp. Bot. 48:173-179.
16. Heagle, A. S., Miller, J. E., Chevone, B. I., Dreschel, T. W., Manning, W. J., McCool, P. M., Morrison, C. L., Neely, G. E., and Rebbeck, J. 1995. Response of a white clover indicator system to tropospheric ozone at eight locations in the United States. Water Air Soil Pollut. 85:1373-1378.

17. Heggestad, H. E. 1991. Origin of Bel-W3, Bel-C and Bel-B tobacco varieties and their use as indicators of ozone. Environ. Pollut. 74:264-291.

18. Heggestad, H. E., and Middleton, J. T. 1959. Ozone in high concentrations as a cause of tobacco leaf injury. Science 129:208-210.

19. Houzeau, A. 1858. Preuve de la présence dans l'atmosphère d'un nouveau principe gazeux, l'oxygène naissant. C.R. Acad. Sci., Paris 46: 89-91.

20. Jacobson, J. S., and Feder, W. A. 1974. A Regional Network for Environmental Monitoring: Atmospheric Oxidant Concentrations and Foliar Injury to Tobacco Indicator Plants in the Eastern United States. Bull. 604. Massachusetts Agricultural Experiment Station, Amherst.

21. Koch, J. R., Creelman, R. A., Eshita, S. M., Seskar, M., Mullet, J. E., and Davis, K. R. 2000. Ozone sensitivity in hybrid poplar correlates with insensitivity to both salicylic acid and jasmonic acid. The role of programmed cell death in lesion formation. Plant Physiol. 123:487-496.

22. Krupa, S. V. 1997. Air Pollution, People and Plants. American Phytopathological Society, St. Paul, MN

23. Krupa, S. V. 1997. Global climate change: Processes and products - An overview. Environ. Monitor. Assess. 46:73-88.

24. Krupa, S. V., and Kickert, R. N. The greenhouse effect: The impacts of carbon dioxide $\left(\mathrm{CO}_{2}\right)$, ultraviolet-B (UV-B) radiation and ozone $\left(\mathrm{O}_{3}\right)$ on vegetation (crops). Vegetatio 104/105:223-238.

25. Krupa, S. V., Pratt, G. C., and Teng, P. S 1982. Air pollution: An important issue in plant health. Plant Dis. 66:429-434.

26. Krupa, S. V., Tonneijck, A. E. G., and Manning, W. J. 1998. Ozone. Pages 2-1 to 2-28 in: Recognition of Air Pollution Injury to Vegetation: A Pictorial Atlas. R. B. Flagler, ed. Air \& Waste Management Association, Pittsburgh, PA.

27. Legge, A. H., Grünhage, L., Nosal, M., Jäger, H.-J., and Krupa, S. V. 1995. Ambient ozone and adverse crop response: An evaluation of North American and European data as they relate to exposure indices and critical levels. J. Appl. Bot. (Angew. Bot.) 69:192-205.

28. Manning, W. J., and von Tiedemann, A. 1995. Climate change: Potential effects of increased

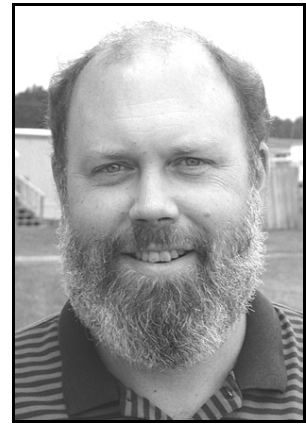

Kent O. Burkey

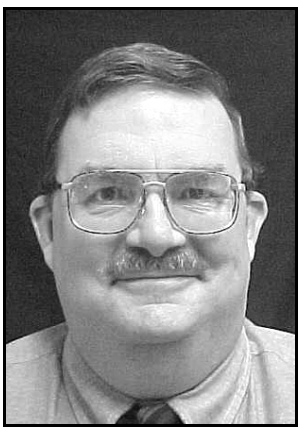

Arthur H. Chappelka

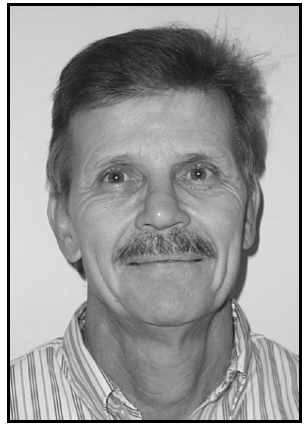

Boris I. Chevone

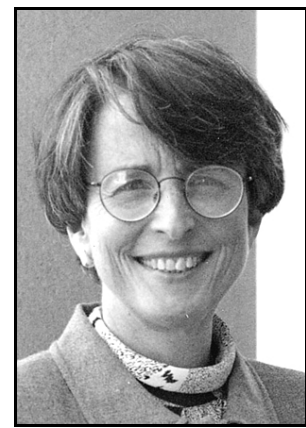

Eva J. Pell

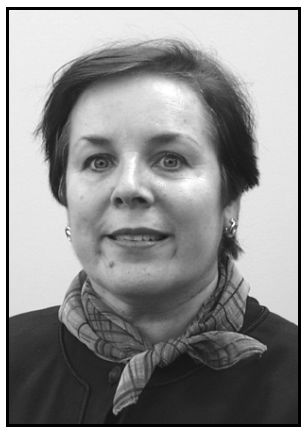

Barbara A. Zilinskas
Dr. Burkey is a research plant physiologist with the USDA Agricultural Research Service and an associate professor of crop science at North Carolina State University. He received his Ph.D. in biochemistry from Ohio State University in 1981. Dr. Burkey joined the USDA-ARS in 1983 to conduct research on chloroplast electron transport that focused on light environment and genetic potential as factors regulating chloroplast function. He moved to the USDA-ARS Air Quality Research Unit in 1995 and began his current research on identification of $\mathrm{O}_{3}$ tolerance mechanisms through studies of $\mathrm{O}_{3}$-sensitive and -tolerant plants.

Dr. Chappelka is a professor in the School of Forestry \& Wildlife Sciences at Auburn University. He received his Ph.D. in plant pathology from Virginia Tech in 1986. Since 1987, Dr. Chappelka has been on the staff within the school investigating the responses of forest trees and associated plant species to air pollutants, primarily $\mathrm{O}_{3}$ and acid rain. His primary interests are in studying the effects of these pollutants on the structure and function of terrestrial ecosystems.

Dr. Chevone is an associate professor in the Department of Plant Pathology, Physiology, and Weed Science at Virginia Tech. He received his Ph.D. from the University of Minnesota in 1974. For the past 25 years, he has been studying air pollutant effects on terrestrial plants. His primary interest is characterizing physiological and biochemical mechanisms involved in $\mathrm{O}_{3}$ tolerance and sensitivity of crop species and forest trees.
Dr. Pell was appointed vice president for research and dean of the graduate school at Penn State University in January 2000. Prior to this, she had a joint appointment in the Environmental Resources Research Institute and Department of Plant Pathology and still serves as the John and Nancy Steimer professor of agricultural sciences. Dr. Pell earned a B.S. in biology from City College of the City of New York, and a Ph.D. in plant biology from Rutgers University. She was appointed as an assistant professor of plant pathology at Penn State in 1973. She was promoted to associate professor in 1978 and professor of plant pathology in 1983. In 1991, she was named distinguished professor of plant pathology, and in 1995 was named the Steimer professor of agricultural sciences. Dr. Pell's research has focused on physiological, biochemical, and molecular aspects of $\mathrm{O}_{3}$ effects on vegetation. In particular, she has developed a framework for understanding the mechanism by which $\mathrm{O}_{3}$ induces accelerated leaf senescence and the implications of this response to the whole plant.

Dr. Zilinskas is a professor at Rutgers University in the Department of Plant Science. She received her Ph.D. in plant physiology in 1975 from the University of Illinois in Champaign/Urbana. She was a postdoctoral fellow at the Smithsonian Institution's Radiaiton Biology Laboratory for 1 year before joining the faculty at Rutgers in the Department of Biochemistry and Microbiology. She received tenure in 1980 and was promoted to professor in 1987. She joined the Department of Plant Science in 1994. Dr. Zilinskas' research program has been focused in the last 10 years on antioxidant enzymes and their role in oxidative stress tolerance in plants. 
atmospheric carbon dioxide $\left(\mathrm{CO}_{2}\right)$, ozone $\left(\mathrm{O}_{3}\right)$ and ultraviolet-B (UV-B) radiation on plant diseases. Environ. Pollut. 88:219-246.

29. McGrath, M. T. 2000. Impact of ambient ozone on clover at Long Island, New York. (Abstr.) Phytopathology 90:S50.

30. McLaughlin, S., and Percy, K. 1999. Forest health in North America: Some perspectives on actual and potential roles of climate and air pollution. Water Air Soil Pollut. 116:151-197.

31. Miller, P. R., and McBride, J. R., eds. 1998. Oxidant Air Pollution Impacts in the Montane Forests of Southern California. SpringerVerlag, New York.

32. Mullineaux, P., and Creissen, G. 1999. Manipulating oxidative stress responses using transgenic plants: Successes and dangers. Pages 525-532 in: Plant Biotechnology and In Vitro Biology in the 21st Century. A. Altman, M. Ziv, and S. Izhar, eds. Kluwer Academic Publishers, Amsterdam.

33. NARSTO (North American Research Strategy for Tropospheric Ozone). 2000. The Narsto Ozone Assessment - Critical Reviews. Atmos. Environ. 34:1853-2332.

34. National Research Council, US. 1992. Rethinking the Ozone Problem in Urban and Regional Air Pollution. National Academy Press, Washington, DC.
35. Orvar, B. L., and Ellis, B. E. 1997. Transgenic tobacco plants expressing antisense RNA for cytosolic ascorbate peroxidase show increased susceptibility to ozone injury. Plant J. 11:1297-1306

36. Pell, E. J., Eckardt, N., and Glick, R. E. 1994. Biochemical and molecular basis for the impairment of photosynthetic potential. Photosyn. Res. 39:453-462.

37. Pell, E. J., Schlagnhaufer, C. D., and Arteca, R. N. 1997. Ozone induced oxidant stress: Mechanisms of action and reaction. Physiol. Plant. 100:264-273.

38. Reddy, G. N., Aeteca, R. N., Dai, Y. R., Flores, H. E., Negram, F. B., and Pell, E. J. 1993. Changes in ethylene and polyamines in relation to mRNA levels of the large and small subunits of ribululose bisphosphate/oxygenase in ozone-stressed potato foliage. Plant Cell Environ. 120:819-826.

39. Richards. B. L., Middleton, J. T., and Hewitt, W. B. 1958. Air pollution with relation to agronomic crops. V. Oxidant stipple of grape. Agron. J. 50:559-561.

40. Sandermann, H. 1998. Ozone: An air pollutant acting as a plant signalling molecule. Naturwissenschaften 85:369-375.

41. Sandermann, H., Ernst, D., Heller, W., and Langebartels, C. 1998. Ozone: An abiotic elicitor of plant defense reactions. Trends Plant Sci. 3:47-50.

42. Sawyer, R. F., Harley, R. A., Cadle, S. H. Norbeck, J. M., Slott, R., and Bravo, H. A. 2000. Mobile sources critical review: 1998 NARSTO assessment. Atmos. Environ. $34: 2161-2181$

43. Schönbein, C. F. 1840. Recherches sur la nature d'l odeur qui se manifeste dans certaines actions chimique. C.R. Acad. Sci. Paris 10:706-710.

44. Schraudner, M., Langebartels, C., and Sandermann, H. 1997. Changes in the biochemical status of plant cells induced by the environmental pollutant ozone. Physiol. Plant. 100:274-280.

45. Schraudner, M., Moeder, W., Wiese, C., Van Camp, W., Inze, D., Langebartels, C., and Sandermann, H. 1998. Ozone-induced oxidative burst in the ozone biomonitor plant, tobacco Bel W3. Plant J. 16:235-245.

46. Torsethaugen, G., Pell, E. J., and Assmann, S M. 1999. Ozone inhibits guard cell $\mathrm{K}^{+}$channels implicated in stomatal opening. Proc. Natl. Acad. Sci. USA 96:13577-13582.

47. U.S. Environmental Protection Agency. 1996. Air Quality Criteria for Ozone and Related Photochemical Oxidants, Vol II. Office of Research and Development, Washington, DC. 